\title{
Prevention of online risk behaviour in schools with regard to the socio-educational activity of the school social pedagogue ${ }^{1}$
}

\author{
Miriam Niklová \\ Matej Bel University, Faculty of Education, Department of Pedagogy
}

\section{Online risk behaviour}

Currently, online risk behaviour is one of the negative socio-pathological phenomena identified by various research studies and surveys of experts in Slovakia and abroad. The Europe-wide survey EU Kids Online (Izrael et al., 2020) investigated the online experience of children aged 9-16. The survey focused on the occurrence of cyberbullying among pupils, contact with harmful content, the issue of data misuse, excessive use of the Internet, sexting, etc. Compared to other countries in Europe, Slovakia is one of the countries with a lower level of children's access to the Internet and at the same time with a lower level of risk experience of children and adolescents in the online environment. The results of the research showed that one in five young people aged 9-16 spend more than 4 hours a day on the Internet, and $47 \%$ of children use the Internet daily to communicate with family or friends. Most children who spend more than 7 hours on the Internet were between the ages of 13 and 14, and there were no significant differences in the gender of the pupils. Almost $65 \%$ of children and adolescents visit social networks daily. $84 \%$ of children and adolescents use the Internet for school-related activities at least once a week. 55\% of children and adolescents use the Internet to play online games every day (Izrael et al., 2020).

There are several variations of online risk behaviour associated with the use of electronic media. As part of the EU Kids Online project, experts specified the most common types of online risk behaviour documented in the following table (See Table 1).

1 The paper is one of the ongoing outputs of the research task VEGA no. 1/0396/20 under the title The influence of electronic media on the behaviour and development of cross-sectional skills of the $Z$ generation. 
Table 1

Classification of online threat children and youth are exposed to

\begin{tabular}{llll}
\hline Alternatives & $\begin{array}{l}\text { content: child as } \\
\text { a recipient } \\
\text { (of mass products) }\end{array}$ & $\begin{array}{l}\text { contact: child as } \\
\text { a participant } \\
\text { (of adult-initiated activity) }\end{array}$ & $\begin{array}{l}\text { action: child as } \\
\text { a perpetrator } \\
\text { (perpetrator / victim) }\end{array}$ \\
\hline aggression & $\begin{array}{l}\text { violent / aggressive } \\
\text { behaviour }\end{array}$ & harassment, stalking & $\begin{array}{l}\text { bullying, hostile behaviour } \\
\text { against peers }\end{array}$ \\
\hline $\begin{array}{l}\text { human } \\
\text { sexuality, }\end{array}$ & pornographic content & $\begin{array}{l}\text { grooming, sexual } \\
\text { harassment in meetings } \\
\text { with strangers }\end{array}$ & $\begin{array}{l}\text { sexual harassment, } \\
\text { sexting }\end{array}$ \\
\hline values & $\begin{array}{l}\text { racism / harmful } \\
\text { content }\end{array}$ & ideological beliefs & $\begin{array}{l}\text { potential harm within } \\
\text { user-generated content }\end{array}$ \\
\hline commerce & build-in marketing & misuse of personal data & $\begin{array}{l}\text { gambling, infringe } \\
\text { copyright }\end{array}$ \\
\hline
\end{tabular}

Online risk behaviour is determined by the child's interaction with the digital environment, which differentiates between the individual forms. In general, opportunities for threats and online threats themselves include, in particular, manifestations of aggression and violence in various forms, sexual threats, problems associated with inappropriate or harmful content and values, commercial risks or misuse of personal data (Livingstone, Davidson, \& Bryce, 2017).

Cyberbullying is among the most common forms of online risk behaviour; therefore, we pay special attention to it. Extensive research focused on the occurrence of cyberbullying was carried out by Chrienová et al.(2019,pp. 7-9) in 2019 in the Lučenec district. 11 primary and secondary schools were involved in the research. The research sample consisted of 1,495 respondents aged 10-17 years. The research authors performed a comparative analysis of the incidence of problematic behaviour among pupils in the period between 2011 and 2019. Research results show that bullying is one of the most frequent and serious manifestations of problematic behaviour among pupils. The most common manifestations of psychological bullying include ridicule and name-calling (1,033 pupils -69.1\%). An interesting finding was also the increase in cyberbullying of teachers by pupils through the Internet (discussion groups on social networks, sharing of photographs, videos).

In the Czech Republic, research was carried out in 2016 by the Centre for Prevention of Risk Virtual Communication at the Faculty of Education, Palacký 
University in Olomouc, which was also supported by the E-Safety project of 02 Czech Republic. They used online questionnaires as a research method, and the research sample consisted of 5,136 respondents. Kindergarten, primary, secondary and tertiary schoolteachers were represented. Research has shown that up to $21.73 \%$ of teachers surveyed have already been victims of cyberbullying by their pupils. Cyberbullying most often took the form of harassment by calling a teacher's mobile phone, threats via phone or the Internet, sending humiliating and ridiculing photos, or misusing a teacher's identity. The most frequent cyber-aggressors were pupils with whom teachers were in regular contact (Kopecký \& Szotkowski, 2016, pp. 5-10).

\section{Prevention of online risk behaviour}

Cyberbullying represents a serious socio-pathological phenomenon. We consider it important to strengthen preventive action in schools, taking into consideration pedagogical, but especially vocational training employees in order to minimize cyberbullying and make the effectiveness of preventive and curative measures more effective.

The increase in risk behaviour in cyberspace and abusive use of the Internet are also discussed in the Strategy of prevention of criminal and other antisocial activity in Slovakia in 2016-2020 (Stratégia..., 2016) within two of the main priorities. The first priority Reduction of criminal and other antisocial activities draws attention to cybercrime and ,the elimination of the promotion of crime through all types of media (film, TV, radio, the Internet, printed matter)". The $5^{\text {th }}$ priority entitled Responding to new trends and threats in the field of security and public order points to the need to prevent crime in the online environment and to prevent addictive dependence on information and communication technologies.

The problems of bullying and cyberbullying are elaborated in Directive $36 / 2018$ on the prevention of and solutions to the bullying of children and pupils in schools and school facilities (Smernica..., 2018). For the first time, Directive 36/2018 also defines cyberbullying, pointing out the possibilities and sequence of preventing and addressing both serious phenomena in schools and school facilities.

At the beginning of 2020, the Government of the Slovak Republic approved the National Concept of Child Protection in the digital space for the period 2020-2025 (Národná..., 2020), the main goal of which is to support effective 
measures in the area of prevention and raising awareness to achieve healthy mental, physical and moral development of children and their protection in the digital space and cybercrime including education, research, rights, political and institutional action, cooperation and coordination at national and international level. The concept is divided into three priorities prevention, intervention and aftercare. The first priority focuses on prevention: Systematic implementation and coordinated support of prevention in the context of child protection in the digital space in Slovakia. A significant priority in the context of child protection in the digital space is the prevention and management of threats present in the digital space. The key role is played by the family, school and other institutions of formal, nonformal and lifelong learning and culture and society as well as the technical security of the digital space in order to create a safe environment for children. It is also necessary to focus prevention on raising awareness of the possibilities of effective solutions to specific dangerous situations. One of the priorities is systematic support for school psychologists, social pedagogues, and school prevention coordinators in schools.

According to Hroncová (2017, p. 80):

A social pedagogue in school as a vocational training employee represents a relatively new profession in Slovakia with the Education Act which defines their relatively wide possibilities of employment in schools and school facilities, but in practice, they are used only to a minimal extent. If there is a social pedagogue in a primary or secondary school, he/she has to deal with many problems and is still a member of an unknown profession compared to other pedagogical and vocational training employees.

The following projects have brought better prospects for the employment of a social pedagogue as a professional employee in schools.

- The PRINED ${ }^{2}$ project was a national inclusive education project with the goal of influencing the kindergarten and primary school inclusive environment and thus ensuring the prevention of unauthorized placement of pupils in the special education system.

- The ŠOV project ${ }^{3}$ (School open for everyone). The aim of the project is to facilitate equal access to quality education and to improve the results

\footnotetext{
2 http://prined.mpc-edu.sk/

3 www.minedu.sk/narodny-projekt-skola-otvorena-vsetkym/
} 
and competencies of children and pupils with the support of inclusive education and the improvement of the professional competencies of pedagogic employees and vocational training employees.

- The national project Helping professions in the education of children and pupils. ${ }^{4}$

We divide online risk (Dulovics, 2018) behaviour prevention in terms of the level and development of risk behaviour into primary, secondary and tertiary. Primary prevention focuses on all pupils regardless of whether or not they have engaged in risk behaviour. As part of primary prevention, the social pedagogue influences the pupil in both the victim and in the assailant roles. On the first level, the task of a social pedagogue is to provide students with e.g., basic information on the safe use of the Internet, as well as information on the importance of following the rules of conduct in virtual communication and to inform them about possible health consequences. He can also inform pupils about the advantages of electronic media and internet in daily life. On the second level, it is important to inform pupils about the possible negative effects associated with electronic media, about the consequences of their potential anti-social behaviour in cyberspace and about the dangers that may arise with their usage.

Secondary prevention is directed to at-risk groups of pupils who are at an increased probability of risk behaviour or of becoming victims of online risk behaviour. As part of secondary prevention, the social pedagogue should pay attention to pupils who are closed, marginalised, come from disadvantaged social backgrounds, but also those affected by certain psychological problems, behavioural problems, or who spend too much time using electronic media.

In tertiary prevention, the role of the social pedagogue is to work with pupils whose chances of risk behaviour or becoming a victim of such online behaviour are increased, with those who have been either victims or aggressors of cyberbullying or some form of cyberbullying, with pupils who have experience with sexting, and as a result have additional problems and with students who exhibited any other form of deviance related to cyberspace.

4 https://www.minedu.sk/narodny-projekt-pomahajuce-profesie-v-edukacii-deti-a-ziakovii-umozni-skolam-obsadit-3-011-pracovnych-pozicii/ 
Miovský (2015) distinguishes three levels of specific primary prevention, which differs from how we had defined it in the context of the issue. General primary prevention focuses on the general population of children and youth without division into more or less risk groups, it takes into account only its age composition and possible specifics given e.g., due to social or other factors.

Selective primary prevention targets groups of people in whom risk factors for the emergence and development of various forms of risky behaviour are present in a more intensive extent.

Indicated primary prevention is aimed at individuals who are exposed to significant risk factors, or in whom manifestations of risky behaviour have already occurred. The aim here is to catch the problem as soon as possible, correctly assess and evaluate the need for specific interventions and start these interventions immediately.

According to Hollá \& Hanuliaková (2015, p. 239), online risk behaviour prevention in schools should be implemented in two ways:

- formal way - during lessons, especially media education and informatics, as well as organizing discussions and lectures, idea exchanges and various workshops. Pupils' media literacy development should focus on working with digital technologies, providing information and making information materials related to online risk behaviour available, and the school climate should be surveyed as part of its development.

- non-formal way - taking the informal, hidden school curriculum represented by the school climate into account and thus implementing non-teaching activities for pupils, developing and supporting the quality of relationships in the school, setting up „boxes of trust" and the like.

The prevention of online risk behaviour and the support of cyber security should be approached systematically from a macro to a micro level - from the national security level, through individual organizations and institutions, individual professionals and pedagogic employees, to the family, which plays a very important role in prevention.

The educational and social environment of the school is referred to as a space in which systems that have a chance to increase resilience to negative phenomena can be applied. On the other hand, school is a space where new problems can be formed and deepened even further, as claimed by Procházka 
(2012, p. 126). The school has an important place in the prevention of all socio-pathological phenomena and there are possibilities to prevent and eliminate negative phenomena that may occur at school.

The educational process belongs to the important forms of prevention of all socio-pathological phenomena in schools. Educational subjects (Ethics as an academic subject, civic education...) have the potential and ability to implement prevention. Within the teaching process, it is important to point out media education. Media education is based on a non-directive approach in the form of a cross-sectional topic or a separate subject; its aim is to teach pupils to evaluate, select and use information as well as to develop their social skills, especially their critical thinking (Niklová, 2015, p. 59). According to the Concept of media education in the Slovak Republic in the context of life-long learning (Koncepcia..., 2009), the goal of media education in primary schools is to increase the media literacy of pupils, form responsible critical thinking in relation to the media, understand the rules of media, critically view its content, be able to understand negative influences and be able to eliminate them, and at the same time the aim is to develop the ability to handle different types of media responsibly.

The Concept of media education in the Slovak Republic in the context of lifelong learning (Koncepcia..., 2009) shows that presently there is no mutual interconnection of activities in the area of media education in Slovakia. Individual activities or projects in the area of media education, which can be assigned the attribute of non-formal education, are aimed primarily at children and adolescents, are implemented by independent institutions, civil associations, church associations or independent experts independently of each other. In many cases they are not mutually informed about their activities and their results, the results of individual partial projects are not subject to any comparison and are not used in a broader and nationwide context. Despite the fact that the concept was developed in 2009, we think that in terms of the overall risk behaviour prevention coordination in the cyberspace environment, no specific unified prevention concept for schools has been created which would ensure optimal and balanced prevention throughout the country. An interdisciplinary approach is important in creating preventive measures against online risk behaviour. Besides cooperation with teaching staff and vocational training employees in prevention, it is relevant to cooperate with police forces, with free time centres, but also with nonprofit organisations and civil associations devoted to prevention. 


\section{Prevention of online risk behaviour from the aspect of a social pedagogue}

In this paper, we pay attention to the prevention of online risk behaviour in children and youth with regard to the tasks of the school social pedagogue. According to Act No. 318/2019 on teaching staff and professional employees (Zákon č. 318/2019..., 2019), a social pedagogue is categorized as a professional employee ${ }^{5}$ of a school. He or she is an expert who not only provides preventive activities, but also provides counselling, diagnoses and re-educates pupils with problematic behaviour. From $1^{\text {st }}$ January 2022, Act No. 414/2021 Coll., amending Act No. 138/2019 Coll. on pedagogical employees and professional employees states that a social pedagogue:

a) carries out preventive activities aimed at prevention and elimination of risky behaviour of children and pupils and prevention and elimination of socio-pathological phenomena;

b) provides counselling and intervention focusing on children and pupils with risk behaviour, at risk of socio-pathological phenomena and children and pupils from socially disadvantaged backgrounds;

c) provides advice and consultation to legal representatives, pedagogical staff and professional staff;

d) carries out socio-pedagogical diagnostics of the environment and relations, awareness-raising activities and other activities in the socio-educational field;

e) supports the cooperation of pedagogical employees and professional staff with legal representatives, employees of social-legal protection of children and social curatorship institutions and other natural persons and legal entities.."

Preventive-educational activities and tasks are performed by a social pedagogue within the competencies declared by the Professional standard of social educators issued as the Instruction of the Minister of Education no. 39/2017 (Pokyn ministra..., 2017). Competencies are divided into three areas:

5 Other professional employees in a school according to this Act include school psychologist, special needs educator, career advisor or speech and language therapist. 
1. area: "Child/pupil" competencies:

- identify the developmental and individual characteristics of the child/ pupil;

- identify and analyse the socio-cultural environment and its influence on the child/pupil;

- identify the specifics of the child/pupil's social and emotional development, social learning and behaviour of the child/pupil;

2. area: "Process of professional activity" competencies:

- possess the knowledge pertaining to the social pedagogy as a study field;

- plan and design socio-pedagogic activities;

- provide prevention;

- provide social education, counselling and consulting;

- provide intervention, re-education and social therapy;

- evaluate the progress and results of the social-pedagogic activity performed with an individual and a group;

3. area: "Career development" competencies:

- Plan and pursue one's own professional growth and self-development; a

- Identify themselves with a professional role and school facility.

Prevention competence is one of the key competencies of a social pedagogue. The social educator has special roles in the prevention of online risk behaviour, including cyberbullying in schools.

The school social pedagogue's socio-pedagogical care for pupils with online risk behaviour is conceived in the following steps:

1. Identification and classification of pupils' online risk behaviour - this is carried out by targeted monitoring and mapping of pupils' online risk behaviour in school. Because online risk behaviour takes place in a virtual environment, it is very difficult to identify it and determine the aggressor(s) and the victims. The manifestation of risk behaviour can be pointed out by the pupils themselves, the teacher, the parent or other pedagogical or professional staff of the school. It is important to examine 
the severity of manifestations of online risk behaviour and its progress. Depending on the severity of pupils' behaviour, other experts are to be contacted.

2. Socio-pedagogic diagnostics - individual diagnoses of pupils for the purpose of an overall diagnosis and creating a full view of the causes and development of online risk behaviour. The pupil's personal history, family history, analysis of the social (family and school) environment, the level of social relations in the class, family, etc. are examined. Within these diagnostic methods, the social pedagogue can apply in particular the method of individual conversation with the involved parties (pupil aggressor, pupil - victim, pupils' parents...), observation, questionnaire, sociometry, etc.

3. Early intervention - selection of adequate methods for working with the student, as well as working with other actors in online risk behaviour (e.g., in cyberbullying, it is a victim, aggressor...). Emphasis is placed on the timeliness of applied professional interventions as a prevention of more seriously delinquent forms of pupil behaviour. After the intervention, which is usually the first choice and is of a short-term nature, a counselling process begins that is regular and long-term.

4. Socio-pedagogical counselling and proposal of specific measures depending on the extent and nature of the pupil's risk behaviour, the social pedagogue continues in individual and group forms of work (individual counselling, training groups, club activities, etc.). The forms and work methods of a social pedagogue or other experts (depending on the nature of the problem, or if other severe manifestations of the child's behaviour a psychologist or child psychiatrist can be contacted...) are determined by the nature and severity of the problem and the overall course of the counselling process. Counselling groups in which there are pupils with similar problematic behaviour are important. When dealing with the pupil's online risk behaviour, it is also necessary to work with the pupil's parents (legal guardians) in an individual or group form and to provide consultations to teachers at school.

5. The feedback and catamnesis - intervention methods applied when working with the pupil and his family and proposal of other preventive measures to maintain adequate behaviour of the pupil. If problems in the pupil's behaviour persist, more intensive and long-term care is needed in 
centres of pedagogical-psychological counselling and prevention and later in special educational facilities (diagnostic centre, re-education centre) in the form of short-term re-education stays or long-term placement in re-education centres, possibly in a medical-educational sanatorium. The catamnesis or the proposal of further measures is important.

Határ also pays attention to the opportunities of the socio-educational care of cyberbullying participants (2018, pp. 176-178).

A prerequisite for effective primary prevention is its regular, systematic implementation, conceived with respect for the age and developmental specifics of pupils. The approach to the prevention of online risk behaviour should be consistent and coordinated with the participation of all actors teaching staff and professional employees, pupils, and last but not least also the pupils' parents. Prevention should be implemented in an attractive way and, in particular, in a form that actively involves pupils.

According to the Internet portal Prevention of Risk Behaviour ${ }^{6}$, one-off events with pupils are considered ineffective by experts; lectures and discussions in which pupils are only passive observers, attending such cultural, sporting and other events in which pupils are only passive participants and after which there is no discussion and analysis of the issue of the event with pupils, are deemed ineffective by experts as well.

Nowadays there are many Slovak projects and programmes which are focused on the prevention of online risk behaviour in relation to the Internet. Bezinternetu.sk project is one of them. Its aim is to regulate the excessive use of the Internet by children and young people. Through the project, pupils are supposed to learn certain principles and guidelines that will reduce the impact of the Internet and digital ICT. Another very interesting project in the field of cyberbullying prevention is the Ktojedalsi.sk project. The project includes a film documentary called Who's Next? which is also a follow-up to previous projects Cookie.sk, Ovce.sk, SÍDLISKOVÝSEN.sk. The film Who's Next? deals with 3 main topics: cyberbullying, killie-selfies related to injuries and death and online sexual abuse. The film is based on real events and reflects today's real-world Internet and its negative effects on children, young people and adults. This film is not intended for all pupils and after the screening of the film, there should be a discussion about the film with the

6 http://www.prevence-info.cz/p-prevence/neucinna-primarni-prevence 
pupils about what the message of the film is and to reflect on the individual parts of the film. Under the auspices of the civic association eSlovakia, the Zodpovedne.sk project was established in 2007, the main task of which was to spread awareness in relation to the safe and responsible use of modern ICT and the Internet. The project should raise awareness in the use of mobile phones and the Internet, especially among children and young people, and thus prevent crime through ICT. Zodpovedne.sk also implemented a few more projects aimed at the prevention, solution and elimination of cyberbullying in children and youth. More information about these projects can also be found on the following Internet portals: Zodpovedne.sk, Kybersikanovanie.sk, neZavislost.sk, Stopline.sk, Pomoc.sk, Detinanete.sk, Preventista.sk, Nehejtuj.sk and other.

Since electronic media are part of the daily life of children and youth, it is necessary to strengthen the preventive-educational influence of school through professional employees. Pupils should learn the principles of safe use of information and communication technologies, with an emphasis on the prevention of cyberbullying, as well as other forms of online risk behaviour. Pupils should be informed about what to do and how they should behave if they or someone around them encounter online risk behaviour, to whom they can turn to for help, and also how to prevent it effectively. A social pedagogue is such an expert in the school environment. However, it is important to emphasize that the cooperation of the whole school community is a prerequisite for effective prevention.

\section{References}

Dulovics, M. (2018). Online rizikové správanie u detí a mládeže a možnosti jeho prevencie prostredníctvom mediálnej výchovy. Banská Bystrica: Belianum.

Hanuliaková, J. \& Hollá, K. (2015). School Social Climate - Cyberbullying Prevention. In A. Szczurek-Boruta \& B. Chojnacka-Synarszko (Eds.), Szkola - kultura - środowisko lokalne pp. 233-242. Toruń : Adam Marszalek.

Határ, C. (2018). Sociálno-edukačná starostlivost' sociálneho pedagóga o aktérov kyberšikanovania (pp. 173-181). E-Świat bez granic i uprezedń. Dabrowa Górnicza: WSB, 173-181.

Hroncová, J. (2017). Sociálny pedagóg v škole v teoretickej reflexii a jeho problémy v praxi. Edukácia, 2(1), 80-88.

Chrienová, M., Majerová Kropáčová, K., Oster, J., \& Osterová, I. (2019). Výskyt nežiadúcich javov v základných školách v okrese Lučenec. Available from http://preventista.sk/info/ prieskum-lucenec-2019/ 
Izrael, P., Holdoš, J., Ďurka, R., \& Hasák, M. (2020). Správa z výskumu EU Kids Online IV na Slovensku - Slovenské deti a dospievajúci na internete. Ružomberok: Katolícka univerzita v Ružomberku. 2020. Available from http://www.ku.sk/images/dokumenty/ff/Sprava_z_ vyskumu_EU_Kids_Online_Slovensko_2018_-_2020.pdf

Koncepcia mediálnej výchovy v Slovenskej republike v kontexte celoživotného vzdelávania schválená uznesením vlády Slovenskej republiky č. 923/2009. (2009). Available from http://195.49.188.210/uploads/9z/9U/9z9UuLgW-4Iwh72hQv9adw/vlastny_material. pdf

Kopecký, K., \& Szotkowski, R. (2016). Národní výzkum kyberšikany českých učitelú - výzkumná zpráva. Olomouc: PF UP.

Livingstone, S., Davidson, J., \& Bryce, J. et al. (2017). Children's online activities, risks and safety. London: LSE Consulting. Available from https://www.gov.uk/government/uploads/ system/uploads/attachment_data/file/650933/Literature_Review_Final_October_2017. pdf

Miovský, M. (2015). Prevence rizikového chování ve školství. Praha: UK.

Procházka, M. (2012). Sociální pedagogika. Praha: Grada.

Národná koncepcia ochrany detí $\mathrm{v}$ digitálnom priestore schválená uznesením vlády Slovenskej republiky č. 63/2020. (2020). Available from https://rokovania.gov.sk/RVL/ Material/24504/1.

Pokyn ministra č. 39/2017, ktorým sa vydávajú profesijné štandardy pre jednotlivé kategórie a podkategórie pedagogických zamestnancov a odborných zamestnancov škôl a školských zariadení. (2017). Available from https://www.minedu.sk/pokyn-ministra-c-392017ktorym-sa-vydavaju-profesijne-standardy-pre-jednotlive-kategorie-a-podkategoriepedagogickych-zamestnancov-a-odbornych-zamestnancov-skol-a-skolskych-zariadeni/

Smernica č. 36/2018 k prevencii a riešeniu šikanovania detí a žiakov v školách a školských zariadeniach. (2018). Available from https://www.minedu.sk/20471-sk/smernicac-362018-k-prevencii-a-rieseniu-sikanovania-deti-a-ziakov-v-skolach-a-skolskychzariadeniach/

Stratégia prevencie kriminality a inej protispoločenskej činnosti schválená uznesením vlády Slovenskej republiky č. 513/2016. (2016). Available from https://rokovania.gov.sk

Zákon č. 318/2019 Z. z. o pedagogických zamestnancoch a odborných zamestnancoch a o zmene a doplnení niektorých zákonov v znení neskorších predpisov. (2019). Available from https://www.zakonypreludi.sk/zz/2019-138

Zákon č. 245/2008 Z. z. o výchove a vzdelávaní a o zmene a doplnení niektorých zákonov v znení neskorších predpisov.

\section{Author}

doc. PhDr. Miriam Niklová, PhD., Matej Bel University, Faculty of Education,

Department of Pedagogy and Andragogy

Ružová 13, 97411 Banská Bystrica, Slovakia, e-mail: miriam.niklova@umb.sk 